\title{
Is Brazil ready for the expected increase in dementia prevalence?
}

\author{
O Brasil está preparado para o aumento previsto \\ na prevalência de demência?
}

\section{¿Está preparado Brasil para el incremento esperado en la prevalencia de demencia?}

Natan Feter 1,2
Jayne Santos Leite

doi: 10.1590/0102-311X00056421

It is estimated that around 50 million people worldwide were living with dementia in 2019, with roughly $60 \%$ living in low- and middle-income countries ${ }^{1}$. This represents a new case of dementia every three seconds ${ }^{1}$. Further, the World Health Organization (WHO) reported that by 2050 (i.e., 30 years later), the expected prevalence of Alzheimer's disease and other dementias is of 152 million cases 1. While the incidence of dementia is stabilizing in some high-income countries 2 , low- and middleincome countries are experiencing a rise in dementia incidence especially due to low educational level and high prevalence of cardiovascular risk factors such as physical inactivity and high fasting plasma glucose $3,4,5$.

Since 1990, the prevalence, morbidity, and mortality attributable to dementia in Brazil increased by 2.5, 3.4, and 2.3-fold, respectively (Institute for Health Metrics and Evaluation. GBD results tool. http://ghdx.healthdata.org/gbd-results-tool\%20). These sustained growths led the country to the second-highest age-standardized prevalence of dementia worldwide in 2016 6. Brazil is facing a demographic transition, with the proportion of the population aged 60 or over reaching $13 \%$ in 2018, expected to double in the next decades. Furthermore, roughly $40 \%$ of dementia cases worldwide can be attributable to modifiable risk factors 7 . This proportion might be even higher in less developed regions such as Latin America, where the proportion of potentially preventable cases of dementia reached $56 \% 8$. A previous study indicated that if no action is taken to reduce the prevalence of such risk factors (e.g., physical inactivity, low educational level), Brazil will face a 4-fold increase in the number of people living with dementia from approximately 927,000 in 2010 to 3,728,000 in 20509.

Nevertheless, the prevalence of these risk factors has increased in the past decade in Brazil. From 2006 to 2018 the prevalence of diabetes in men and women increased 54\% and 28\%, respectively, while the proportion of Brazilians with overweight (body mass index - BMI $\geq 25 \mathrm{~kg} / \mathrm{m}^{2}$ ) increased $19.7 \%$ and $38.9 \%$, respectively 10. Also, in 2019 one third of Brazilian adults aged 25 or over did not complete primary education. Moreover, only $39 \%$ of the adult population in Brazil achieved the WHO guidelines for physical activity in 2019 10. Although this proportion increased from 19.4\% in 2010 11, older adults (i.e., 65+ years) were less active in 2019 (24.4\%) compared to 2010 (36.7\%). The lack of sufficient awareness about the importance of controlling these and other risk factors at the populational level might underestimate the calculated number of people living with dementia in Brazil in the next 30 years.
1 Universidade Federal de Pelotas, Pelotas, Brasil. 2 The University of Queensland, St. Lucia, Australia.

Correspondence N. Feter

Rua Luís de Camões 625, Pelotas, RS 96055-630, Brasil. natanfeter@hotmail.com 
In response to the alarming scenario associated with the burden of dementia in the world, the WHO created the Global Dementia Observatory in 2018 12. It provides standardized national-level information about the burden of dementia and public health policies in countries worldwide. This new approach enables us to look at how some countries are responding to the current situation and acting to mitigate the chaotic scenario regarding the expected increase in the burden of dementia especially in low- and middle-income countries in the next years.

Nevertheless, Brazil has no data for any indicator available in the Global Dementia Observatory. Although we have the highest prevalence of Alzheimer's disease and other dementias in Latin America, no national dementia control plan, dementia awareness campaign, and data available about diagnostic rate 13 are available. In 2019, the Brazilian Senate received the first law project to create the Brazilian National Dementia Plan (PL n. 4,364/2020) 13. However, due to the lack of political support, the project status has not changed since August 2020. On the other hand, other policies such as the one that extinguishes the minimal budget for health and education (PEC $n .186 / 2019)$ have received higher priority.

Unlike countries that are facing a decline in dementia incidences such as the United States and England 2, Brazil has no funding available for dementia-specific research plans or programs. Most research on this topic in the country receives no funding from the federal government, being funded by international or private institutions. For example, the STRiDE project (Strengthening Responses to Dementia in Developing Countries - https://stride-dementia.org/), a multi-cultural project that aims to strengthen the response to dementia in developing countries (i.e., Brazil, Jamaica, India, Indonesia, Kenya, Mexico, South Africa), is supported by the UK Research and Innovation Global Challenges Research Fund (ES/P010938/1). In Brazil, the Federation of Brazilian Alzheimer's Associations (Febraz), a private non-profit organization, collaborated with the STRiDE project. Robust funding for dementia-related research enhances the likelihood of developing disease-modifying treatment, and contributes to the elaboration of well-designed public health strategies to preserve the health and well-being of people with dementia and their caregivers in Brazil ranging from access to the health system to enhanced quality of life.

Furthermore, healthcare systems around the globe were partially or fully disrupted by the COVID-19 pandemic ${ }^{14}$. People living with diabetes, cancer, dementia, and other chronic diseases had the support for treatment suspended so patients with COVID-19 could be assisted to mitigate the number of deaths by this infectious disease ${ }^{14}$. However, those chronic conditions were still affecting different aspects of patients' health. Moreover, people aged 60 or older and with any neurological disease are the groups with the highest risk of mortality due to COVID-19 in Brazil 15. People with dementia who were admitted without known COVID-19 had a higher risk of infection and death by the virus than other people in the same community 16 . The COVID-19 pandemic has also asked the older population to stay at home to reduce virus transmission, infections, and deaths. However, social distancing is not social isolation 8 . Low social contact caused approximately $4 \%$ of all dementia cases in the world. Large-scale programs to promote COVID-19-safe, age-friendly social interactions are crucial for preserving the mental health of the older population in Brazil 17.

Still, dementia in Brazil is undertreated and underdiagnosed. The stigma associated with this disease thwarts campaigns to increase awareness for dementia. We are puzzled by the COVID-19 pandemic. Intensive care units are no longer sufficient. Robust healthcare systems are completely disrupted. People are dying without any medical support due to scarce resources in hospitals and medical centers. However, what is the future holding for us? The persistent decline in funding for scientific research 18,19 aligned with the disrupted political and economic support for the Brazilian Unified National Health System 20 (known as SUS, for its initials in Portuguese), and the lack of the national dementia control plan might create conditions for a chaotic scenario for people living with dementia in Brazil in the future. Approval of the national dementia control plan is urgent. This might be the first step for increased awareness of dementia in Brazil. Controlling risk factors, reducing inequity in access to education, and efficient support for caregivers are critical actions expected from the Brazilian government. Otherwise, the disrupted healthcare system observed in Manaus in 2020 and 2021 due to the COVID-19 pandemic might be confounded as a déjà vu in 2050. 


\section{Contributors}

Both authors contributed equally in the production of the article.

\section{Additional informations}

ORCID: Natan Feter (0000-0001-6295-9792);

Jayne Santos Leite (0000-0002-4612-7301).

\section{References}

1. World Health Organization. Global action plan on the public health response to dementia 2017-2025. Geneva: World Health Organization; 2017.

2. $\mathrm{Wu}$ Y-T, Beiser AS, Breteler MMB, Fratiglioni L, Helmer C, Hendrie HC, et al. The changing prevalence and incidence of dementia over time-current evidence. Nat Rev Neurol 2017; 13:327.

3. Ding D, Zhao Q, Wu W, Xiao Z, Liang X, Luo $\mathrm{J}$, et al. Prevalence and incidence of dementia in an older Chinese population over two decades: the role of education. Alzheimers Dement 2020; 16:1650-62.

4. Ding M, Qiu C, Rizzuto D, Grande G, Fratiglioni L. Tracing temporal trends in dementia incidence over 25 years in central Stockholm, Sweden. Alzheimers Dement 2020; 16:770-8.

5. Maestre GE, Mena LJ, Melgarejo JD, et al. Incidence of dementia in elderly Latin Americans: results of the Maracaibo aging study. Alzheimer's Dement 2018; 14:140-7.

6. GBD 2016 Dementia Collaborators. Global, regional, and national burden of Alzheimer's disease and other dementias, 1990-2016: a systematic analysis for the Global Burden of Disease Study 2016. Lancet Neurol 2019; 18:88106.

7. Livingston G, Huntley J, Sommerlad A, Ames D, Ballard C, Banerjee S, et al. Dementia prevention, intervention, and care: 2020 report of the Lancet Commission. Lancet 2020; 396:413-46.

8. Mukadam N, Sommerlad A, Huntley J, Livingston G. Population attributable fractions for risk factors for dementia in low-income and middle-income countries: an analysis using cross-sectional survey data. Lancet Glob Health 2019; 7:e596-603.

9. Oliveira D, Jun Otuyama L, Mabunda D, Mandlate F, Gonçalves-Pereira M, Xavier M, et al. Reducing the number of people with dementia through primary prevention in Mozambique, Brazil, and Portugal: an analysis of populationbased data. J Alzheimers Dis 2019; 70 Suppl 1:S283-S91.

10. Departamento de Análise em Saúde e Vigilância de Doenças Não Transmissíveis, Secretaria de Vigilância em Saúde, Ministério da Saúde. Vigitel Brasil 2019: vigilância de fatores de risco e proteção para doenças crônicas por inquérito telefônico. Estimativas sobre frequência e distribuição sociodemográfica de fatores de risco e proteção para doenças crônicas nas capitais dos 26 estados brasileiros e no Distrito Federal em 2019. Brasília: Ministério da Saúde; 2020

11. Iser BPM, Yokota RTC, Sá NNB, Moura L, Malta DC. Prevalência de fatores de risco e proteção para doenças crônicas nas capitais do Brasil - principais resultados do Vigitel 2010. Ciênc Saúde Colet 2012; 17:2343-56. 
12. World Health Organization. The Global Dementia Observatory reference guide. Geneva: World Health Organization; 2018.

13. Senado Federal. Projeto de Lei no 4364, de 2020. Institui a Política Nacional de Enfrentamento à Doença de Alzheimer e Outras Demências e dá outras providências. https://www25. senado.leg.br/web/atividade/materias/-/ materia/144381 (accessed on 13/Jan/2021).

14. World Health Organization. Pulse survey on continuity of essential health services during the COVID-19 pandemic: interim report. Geneva: World Health Organization; 2020.

15. Baqui P, Bica I, Marra V, Ercole A, van der Schaar M. Ethnic and regional variations in hospital mortality from COVID-19 in Brazil: a cross-sectional observational study. Lancet Glob Health 2020; 8:e1018-26.

16. Livingston G, Rostamipour H, Gallagher P, Kalafatis C, Shastri A, Huzzey L, et al. Prevalence, management, and outcomes of SARSCoV-2 infections in older people and those with dementia in mental health wards in London, UK: a retrospective observational study. Lancet Psychiatry 2020; 7:P1054-63.
17. Schmidt MI, Duncan BB, Silva GA, Menezes AM, Monteiro CA, Barreto SM, et al. Chronic non-communicable diseases in Brazil: burden and current challenges. Lancet 2011; 377:1949-61.

18. Mega ER. Financial crisis looms at Brazilian science agency. Science 2019; 365:731.

19. Oliveira EA, Martelli Júnior H, Silva ACS, Martelli, DRB, Oliveira MCL. Science funding crisis in Brazil and COVID-19: deleterious impact on scientific output. An Acad Bras Ciênc 2020; 92:e20200700.

20. Castro MC, Massuda A, Almeida G, MenezesFilho NA, Andrade MV, Noronha KVMS, et al. Brazil's unified health system: the first 30 years and prospects for the future. Lancet 2019; 394:345-56. 